\title{
Exploring Justitia Through Éowyn and Niobe: On Gender, Race and the Legal
}

\author{
Patrícia Branco ${ }^{1}$
}

(C) Springer Science+Business Media Dordrecht 2017

\begin{abstract}
The image of Lady Justice, a white woman, sometimes appearing with her eyes veiled and other times unveiled, at times bearing scales and/or a sword in her hands, still is a common and popular feature of legal culture in many parts of the world. This is an image of justice that is found everywhere, from courthouses to cartoons. However, one may ask: "Who is this woman?"; Is she really a worthy representative of justice?; Or even a commendable representative of women? Thus, in this article, it is proposed to question the image of Lady Justice and the interpretations that have been associated with it, as well as the standards of conduct required of, and imposed upon, women both inside and outside the legal profession. The article will consider a range of arguments related to such questions, particularly on the issues of gender and race, by using two female characters: Éowyn (from Tolkien's The Lord of the Rings) and Niobe (from the Wachowskis's The Matrix). The two characters are women who have some significance in both plots. Through them, I will establish some similarities and differences with Justitia, namely the need to be disguised as men or embrace male attitudes (a similar process concerning women in the legal profession, for example); the use of weapons (specifically, the sword, and, hence, the necessary analysis of women as law breakers, in contradiction to the image of Justitia); and finally some key issues relating to the representation of women of colour.
\end{abstract}

Keywords Lady Justice $\cdot$ Law $\cdot$ Gender $\cdot$ Race $\cdot$ Legal profession

Patrícia Branco

patriciab@ces.uc.pt

1 Centro de Estudos Sociais, Universidade de Coimbra, Colégio de S. Jerónimo, Apartado 3087, 3000-995 Coimbra, Portugal 


\section{Justitia, or Lady Justice: Some Attributes}

My interest in the allegory of Justitia came by chance, intertwined with the analysis of courthouse architecture. During my academic studies I never paid much attention to or examined the image of justice embodied in courthouse architecture. Therefore, I didn't give much importance to the allegory of Lady Justice, either. As we know, justice imagery is an ornament present in many of the courts' spaces. An ornament that has become increasingly rare in many countries (as in Portugal, my homeland) particularly when the image the decision-makers want to give of justice is that of informality, computerization, bureaucracy and speediness (Branco 2016). Nevertheless, the imagery of justice is still a common and popular feature of different legal cultures in many parts of the world. However, the prominent image that has affected us most is that of Justitia, or Lady Justice. From the Renaissance onwards, standardized images of Justitia became so omnipresent in courthouses, law books and law schools, and in a variety of forms including paintings, stain glass, and product labels, that these representations developed a weight of a "given", of a modern quasi-religious, quasipolitical icon (Resnik and Curtis 2011; Mulcahy 2013).

As Sprague (2011) claims, Lady Justice guards the entrances to our historic courthouses $^{1}$ and stands as a statuary example of all that is good and worthy in our system of administering justice. Classically, Lady Justice is commonly shown carrying a set of scales and a sword, and since the sixteenth century often wears a blindfold. The scales are said to depict a careful and emotionless balancing of arguments (de Ville 2011), the blindfold portrays her impartiality, and the sword illustrates the power of the State. The history of the scales, associated with divine judgment, allows us to trace the origin of modern images of Lady Justice beginning with god Shamash (in Babylonia), passing by Ma'at (in Egypt), also embodied in the Greek and Roman goddesses (Dikê and Themis). And then the Romans coined 'Justitia'. Afterwards the Justice imagery came to be mingled with the Catholic Church, through St. Michael, often depicted weighing souls and wielding a sword to slay Satan's dragon.

In the middle ages, images of Justitia are characterized by a combination of Christian and Greek-Roman thinking (de Ville 2011). By this time, Justitia had become one of the four cardinal virtues fighting against the vices of humanity. In fact, Justitia appeared alongside Prudence, Strength and Temperance. This quartet was often also represented with the Catholic virtues of Faith, Hope and Charity. Nevertheless, the remarkable longevity of Justitia has not been shared by her sisters (Resnik and Curtis 2011).

But, who is this woman?: Is she really a worthy representative of justice?: Symbolic of women? In this article I argue that we are facing a deceitful image.

\footnotetext{
1 And yet, the female image of justice, even if it is present in courthouses, has served the exclusion of real women from the courts. We cannot forget that the physical spaces where justice is rendered and administered, the courts, were spaces in which the law was administered by men-from legislators to judges, prosecutors, lawyers and court officials. Mulcahy has also argued that the courthouses' buildings, with their columns, suggest a masculine aesthetic: so, we would have a Lady-Justice living inside a palace made, administered and run by men. Notes taken during the seminar «Architecture and Political Representation: The uncontrollable impulse of the feminine», presented in September 2011 at Centro de Estudos Sociais, in Coimbra. Cf. http://www.ces.uc.pt/eventos/index.php?id=3699\&id_lingua=1 [last accessed 05/06/2016).
} 
Look harder! Ignore assumptions on the force of punishment, the balancing of values and interests, impartiality and neutrality. She is supposed to be Virtue, an ideal and an example of perfection. Look again at the woman! Look at her female body; her skin colour! Pay attention to the fact that she is holding a sword.

Capers (2012) argues that every image we see of Justitia is a type of reproduction and repetition. Which makes it a matter of intertextuality as well, for every image of Justitia we see and every reading we make of it depends on prior codes, connecting the image to other stories and other images. Furthermore, it is not a passive image, for it communicates to us (Capers 2012). And it is what it communicates that I want to examine here. Different from Goodrich's analysis of legal emblems, my referent here will be contemporary and vernacular rather than classical (Goodrich 2014). Still, as this author claims, we need to be a touch more irreverent when it comes to justice and the politics of law.

I believe this allegory has many layers of significance and of interpretation. As lawyers, we usually are more concerned with the meaning it conveys in terms of the ideal of justice and judgment. As we know, visual images of law and justice have contributed in a very important way to the creation of a mental image of justice that supports the belief in an obligation to obey the law in a given way (Nettel 2005). An allegory centuries old, that borrowed and made its own elements that have been lost over the years or that have gained other meanings, different from what was originally intended. I will not analyse the history of this allegory, since others have done it before me, but her prominent features will be here considered and examined. Yes, we have learned to recognize the allegory, but, it is suggested here that we do not question it sufficiently. What I want is to look at other, perhaps, more subtle meanings, hidden in those layers. I argue that Lady Justice imposes expectations on women, be it as legal professionals, as victims or as offenders.

Thus, with the use of some of the materials collected during fieldwork on courthouse architecture in Portugal, as well as images that colleagues and friends have sent me (and that can be easily traced on the internet), I intend to observe and question the allegory of Lady Justice, or Justitia, discussing some of her attributes in the context of the twenty-first century. Particularly, what concerns the behaviours and expectations required from and imposed upon women by the law, for women are still forced to conform to "lady-like" expectations. Thus, I propose to question the image of Lady Justice, and in this process, I will, in particular, point to the issue of gender, especially in what concerns the behaviours which are required and imposed upon women, inside the legal profession and/or when they adopt illegal conducts. I will also address the issue of race. As previously mentioned, I will do so by using two female characters, from literature and cinema: Éowyn (The Lord of the Rings, by Tolkien) and Niobe (The Matrix franchise, by The Wachowskis). And finally, I mean to place the Portuguese reality in a wider context, especially in a historical moment when Justice, in Portugal, is headed by a group of women. In 42 years of democracy, Portugal has had three female Ministers of Justice, and for the first time, she is a black woman ${ }^{2}$; the second

\footnotetext{
${ }^{2}$ Cf. http://www.portugal.gov.pt/pt/ministerios/mj.aspx [last accessed 05/09/2016].
} 
female as Head of the Lawyer's Bar ${ }^{3}$; and for the first time a female General Prosecutor ${ }^{4}$ - all of them female lawyers.

\section{The Gender of Justitia: Women, Virtues and Expectations}

Hence, Lady Justice is commonly represented as a woman. However, this has been an attribute seldom discussed. The personification of justice as a woman should be regarded as more than simply a remnant of the appropriation of certain attributes from the Egyptian, Greek and Roman goddesses. As Robert (1993) argues, you need an abstraction, a female abstraction, to ensure the complete neutrality of an image. Mulcahy (2013) also claims that representations of women were usually made by male artists, in which the desires, fantasies and constraints of patriarchal culture are imposed on womankind. Women were used by male artists to stand allegorically for chastity, but they did so by becoming men or by denying the properties that men perceived as female.

Goodrich (1995) claims that the fact justice is represented as a woman connotes further ironies. One such irony was the re-emergence, in the sixteenth century, of the symbolization of justice as a blindfolded woman. Women, by virtue of their worldliness or reproductive force were a threat to the temporal order of political sovereignty and the logic of law. According to Goodrich (1995), the vice of femininity was precisely its nature, its plurality, both its diversity and its ability to reproduce, both its inconstancy over time and its production of difference. The author thus questions: "How better to repress the body than by closing its eyes and forcing it into an internal and dark world of the spirit? How better to figure the control or subjection of a woman and of her passion than by hiding her eyes... from the vision of the law?"(Goodrich 1995: 158). Lee (2012) also considers that the blindfolding would not have happened if justice had been represented as a man, giving the example of St. Michael, who is always depicted with his eyes opened. Thus, as this author suggests, the blindfold was imposed on Lady Justice as a way to domesticate women; which would have to be done necessarily by (rational) men as rulers (and creators of legal norms) and as judges (as interpreters and applicators of said norms). During the Middle Ages there was as well the cult of another female figure, that of Virgin Mary, the mother, mediator and ideal of rightness, an omnipresent iconic symbol, that, as Robert (1993) argues, will provide an ecclesiastical female symbol to the duties performed exclusively by men.

There is, therefore, an ambiguity in femininity, which is based on a system of conflicting representations, where the positive qualities recognized to the 'fair sex' (motherhood, care, or mediation) are systematically offset by strongly negative characteristics, such as attraction, emotionality, imagination or softness of character. Thus, one can say that this idea of femininity is linked to that of virtue, virginity, as well as child-rearing and housework. In this context of motherhood and

\footnotetext{
${ }^{3}$ Cf. http://portal.oa.pt/ordem/historia/bastonarios-e-mandatos/ [last accessed 05/09/2016].

${ }^{4}$ Cf. http://www.ministeriopublico.pt/pagina/procuradora-geral-da-republica-0 [last accessed 05/09/ 2016].
} 


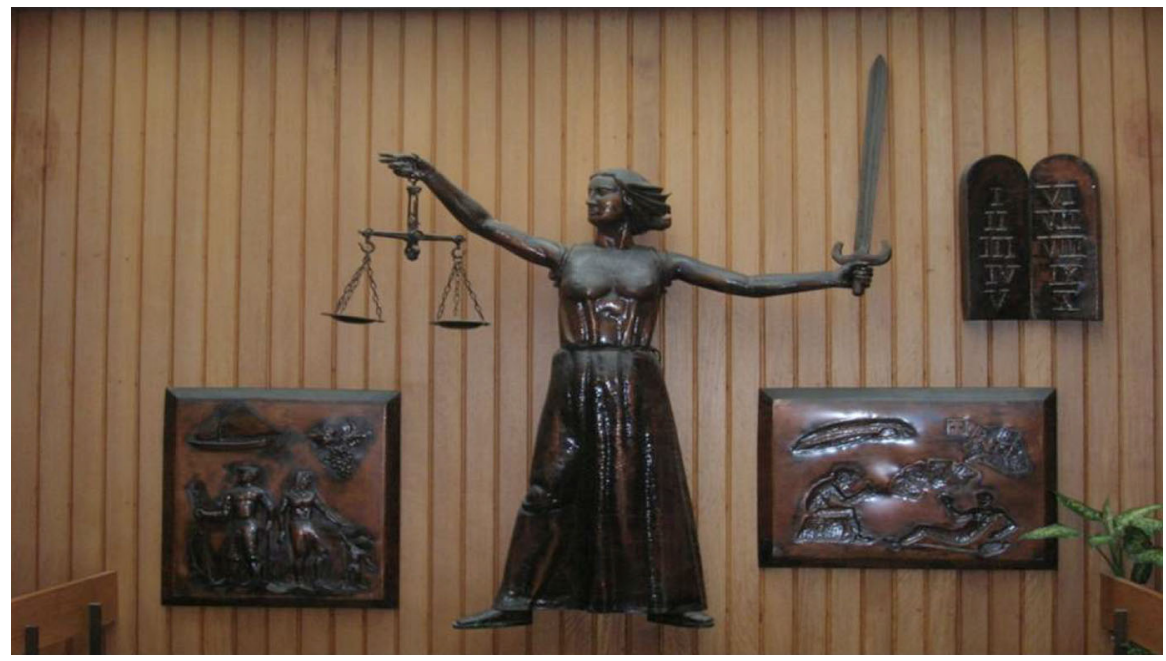

Fig. 1 Justitia, S. Roque do Pico, Court Hall: From the author's personal archive

consequently of family issues, allow me to examine the image of Lady Justice in the Judicial Court of São Roque do Pico, in the Azorean archipelago, built in the 1980s (Fig. 1).

The courthouse building is not aesthetically interesting. Nevertheless, it is located in the central square of the village and it offers a fantastic view of the Atlantic Ocean nearby. When we enter the hall, we are greeted by the image of a sperm whale, one of the animal-symbols of these Azorean islands. And as we climb the spiral staircase to the first floor, where the courtroom is located, we are faced with this image of Lady Justice holding the scales and a sword, but without the blindfold. There is also a panel alluding to the Ten Commandments; and two other panels, one on each side of Lady Justice, as illustrations of moral and upright behaviour, on the one side, as opposed to unruly and immoral behaviour, on the other side. And here we could make a brief parallel with Giotto's Giustizia and Ingiustizia, especially the images beneath each of them: the first are scenes of two knights going off to hunt, some young women dancing happily to the sound of musical instruments, and two merchants heading to the city to sell their wares. Scenes that are the fruit of the justice that rules in the city. Beneath the figure of Injustice there are only scenes of death, desolation and violence (Shklar 1990).

Returning to the Portuguese Lady Justice: This imagery is all-pervading, since it accompanies us up the stairs (emerging at a higher level) and watches us as we wait in the waiting area that leads to the court registry and the courtroom. The image of Justitia is not particularly appealing, at first sight. It is the two panels that flank it (which can be read as the positive and the negative of a photography) that give us something to reflect upon: the panel on the right side, in bas-relief, shows a couple that makes its living out from working the land (the grapes) and at sea (the fishing boat); and we see the mother holding the couple's child by the hand. This image conveys a very traditional and heteronormative meaning: the transmission of values 
linked to the ideal of family, made of the marital relationship between persons of different sex, and the vision of the mother as the caregiver, in compliance with the rules, legal and social. In turn, the panel that appears on the left side displays the images in a hollow, with two men who are visibly drunk and gambling, and the boat is seen overturned, which has to be read as a reference to dissolute behaviour, a behaviour that goes against the rules. As a friend suggested, the overturned boat could be read as a lesson to a fishing community of the dire consequences of bad behaviour, and perhaps the boat could even be seen as an allegory for society as a whole. What is also clear in this panel is the absence of women, as if their absence could be the cause of these men's decadent and dissolute actions. And although Lady Justice does not have a striking figure, her gaze indicates the direction to follow, while the sword emphasizes the reprehension of bad deeds. Justitia's posture is not passive or indifferent. On the contrary, her gaze is rather normative, imposing behaviours and admonishing sanctions. Furthermore, the panel alluding to the Ten Commandments is also worth mentioning, for it clearly states what people shall and shall not do.

As we are well aware, and these images definitely point that out, we live in a world that continues to see women as responsible for relationships and children. According to Levit and Verchick (2006), marriage and family form the anchor of a gendered social system that makes women vulnerable to exploitation and abuse. This vulnerability stems from the expectation that women are the primary caregivers of children, who will rely on the economic support of their husbands and will take care of most of the housework, regardless of the fact they also work outside the home. The Law-either the legislation or the judiciary-emerges, thus, as a false neutral, based on the values of universality, equality and neutrality, and under the cover of this apparent neutrality, it does not do much more than reproduce the status quo in place. From the study of a sample of 194 completed cases regarding the regulation of parental responsibilities in two Portuguese family courts, in 2010, in Lisbon, the country's capital city, and Braga, in the northern part of the country, the researchers concluded that the custody of the children was assigned to the mother in the vast majority of cases (in $77 \%$ of cases in Lisbon and in $72 \%$ of cases in Braga). The predominance of custody cases assigned to the mothers is associated by the respondents in this research (judges and lawyers) to the pre-existing societal gender inequalities, especially when it comes to the exercise of parental responsibilities. Which was also reinforced by the ideology of the judges, present in some of the analyzed decisions, where the judges stressed the 'normal', the essential and irreplaceable nature of maternal affective compensation, based, as was claimed, in the current status of case law and in 'modern psychology' (Pedroso et al. 2014).

From another standpoint, we cannot forget that women are still the object of male violence, especially inside the home, even if in many countries domestic violence is now a matter of criminal procedure..$^{5}$ Over the past 11 years, there were 428 femicides and 497 crime attempts in Portugal. In 2014, domestic violence was responsible for one death per week in Portugal—and here one shall read a woman

\footnotetext{
5 In Portugal the crime of domestic violence is substantiated in the penal code since 2007 (article no. 152.).
} 
dead per week. In terms of the relationship between the murdered women and the murderer, the most expressive group is that of women who maintained or had had an intimate relationship with the murderers, corresponding to $81 \%$ of all women who were killed in 2014 (UMAR 2015). The profile of these women fits the profile of many others: that of mother and financially independent woman-the most relevant group is that of women aged between 36 and 50 years, similar to that of the murderers. And in most cases, the woman was murdered in the place she should be safest-her own home (UMAR 2015).

Historical and political factors have been significant in producing a gender oppressive legal environment in which women have been subjugated on a global scale (Shaw 2010). It is thus important to remember our legal history of indifference to issues of domestic violence, alongside the stereotype still reflected in numerous judicial decisions: that some of these women, because of some of their actions, were also somehow guilty of their death. That is to say, guilty of non-compliance with what was expected from them as women and wives. One example of such type of decisions is that from the Portuguese Supreme Court, Acórdão no. 04P1389, ${ }^{6}$ from 2004 , in which the judges considered there were no reasons to aggravate the murder because the accused should benefit from some mitigating factors, such as his illiteracy, on the one hand, and, on the other hand, the fact that the victim, "without one knowing why-ignorance once again favourable to the defendant"-had refused to maintain sexual intercourse with him for some time (during the two months prior to the murder, which took place in front of the couple's children), "a circumstance that allows the assertion that it was not only the accused who violated marital duties, and may even help explain the doubts raised in that dimly lit mind about the wife's (in)fidelity". But if one reads through the decision, the court declared that it had been proved the husband was violent and offensive, so one can hardly say the wife's behaviour came out of the dark. And even if there were no reasons behind her refusal, how come it can be seen as a mitigating factor?

That is why Banksy's statue, ${ }^{7}$ using the Old Bailey as a model, is such a wonderful vehicle for criticizing the legal system and the judiciary. This image of a slut and transgressive Justitia raises questions on how the law has dealt with prostitution and women prostitutes, seen as deviants and thus subjected to control mechanisms via the criminalisation of their conducts. In addition, as several decisions in different countries have demonstrated, women who have had a variety of sexual experiences with a number of men, whether for money or not, are 'better' targets for men who rape, that is, as long as they direct their actions at women in this category, men will gain lesser penalties for rape, whatever the circumstances of the rape (Scutt 1991). Contrary to Lady Justice, these women's bodies were not veiled, so they have tempted men and thus cannot stand for virtue.

The legal system also continues to require that women, in accordance to the ladylike stereotype, resist sexual attack 'until exhausted or overpowered' in order to

\footnotetext{
${ }^{6}$ Retrieved from http://www.dgsi.pt/jstj.nsf/954f0ce6ad9dd8b980256b5f003fa814/6cb04efb29c195ab80256 eb50034dd38?OpenDocument [last accessed 05/09/2016].

${ }^{7}$ The statue can be seen here: http://news.bbc.co.uk/2/hi/entertainment/3537136.stm [last accessed 06/09/2016].
} 
establish rape (Capers 2006). As was the case in 2011 with the decision by Oporto's Court of Appeal, Acórdão no. 476/09.0PBBGC.P1, ${ }^{8}$ when a psychiatrist, after having been declared guilty by the court of first instance, was then acquitted and declared not guilty of raping one of his patients, during one of her medical visits to his office. The patient was pregnant at the time of the event (in her 34th week of pregnancy); however, the judges considered that mere verbal refusal was insufficient to confirm the occurrence of such crime. The Court then deliberated that "the victim's resistance must be evident, unmistakable and appropriate in order to oppose the act".

But Banksy's Justitia has to do as well with the imposition of stereotypes linked to femininity and virtue, structured around two extreme poles: the sexually voracious woman and the asexual respectable woman-which Banksy seems to condense into one in his re-elaboration of Justitia. And on the issue of the sexually voracious woman we can consider here the importance the law gives to biological kinship, especially when a child born out of wedlock is registered by the mother without mentioning the father. If, on the one hand, one is aware and respects the importance of the best interest of the child, namely the right to have a family, on the other hand, it is important to consider how the law still regards women that decide to take care of children on their own, without a male partner. When it comes to ex officio investigations of fatherhood, the sexual conduct of women is still of primal importance to the court, even in the era of DNA exams, as Machado (2007) has shown. This author presents the judicial investigation of paternity as a context that reveals the views of legislators and judges about the ways women should behave, by means of standard-setting procedures, associated with a sexist bias through the use of scientific tests to determine the biological paternity. It follows that women's citizenship in Portugal remains limited and conditional, in particular in situations where there is an accumulation of vulnerabilities associated with class position, economic or labour dependency and sexual and procreative behaviour considered as deviant (Machado 2007).

Regarding the asexual respectable woman, it is worth mention a 2014 decision taken by the Portuguese Administrative Supreme Court-Acórdão no. 0279/14 ${ }^{9}$ that reduced the amount of compensation decided by the lower court, which was to be paid by a hospital to a woman as the result of a defective surgery (Bartholin's gland ablation in which the surgeons mistakenly cut one of the nerves) with severe consequences on her sexual organs and sexual activity, ${ }^{10}$ thus affecting her whole life, including her labour capacity. The reduction of the compensation amount was based on the argument, as the Court ruled, that after the age of 50, sexuality does not have the same importance it has at a younger age. A decision in line with the stereotype of a lady-like behaviour. It is somehow amusing to think that the collective of judges (two men and one woman) were way over their fifties.

\footnotetext{
${ }^{8}$ Retrieved from http://www.dgsi.pt/jtrp.nsf/0/1c550c3ad22da86d80257886004fd6b4?OpenDocument [last accessed 05/09/2016].

${ }^{9}$ Cf. http://www.dgsi.pt/jsta.nsf/35fbbbf22e1bble680256f8e003ea931/683aef3e81f7522480257d70004 aee6f?OpenDocument\&ExpandSection=1 [last accessed 06/09/2016].

${ }^{10}$ Check the New York Times for more information: http://www.nytimes.com/2014/11/04/world/europe/ sex-after-50-less-important-for-women-portuguese-court-rules-.html?_r=1 [last accessed 06/09/2015].
} 


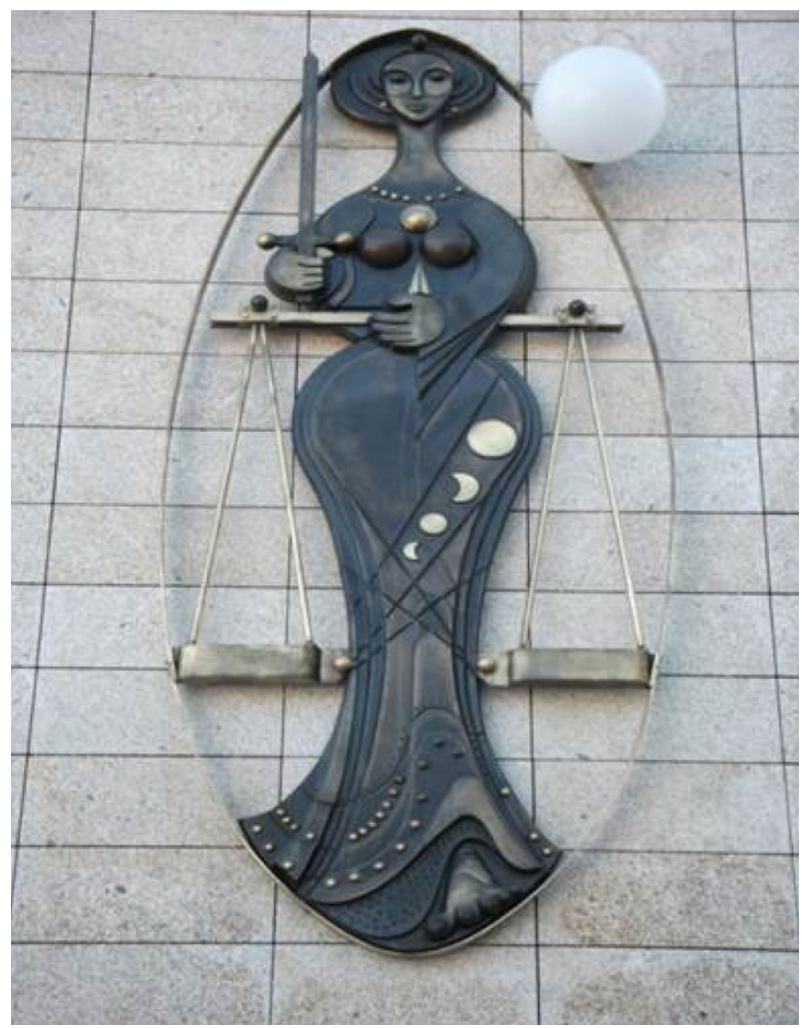

Fig. 2 Lady Justice, Vila Nova de Famalicão, Court Façade: from the author's personal archive

In this day and age, and as Dowd (2013) asserts, attributes associated with men, such as leadership, strength, agency, assertiveness, and rational choice, create double binds for women, who are neither respected nor valued, and may even be criticized, if they display these characteristics. Also accounts for the misidentification of gender harms when men are involved due to the general pattern of male power and privilege. Hence, rationality and logic are characteristics that have been considered as typically male. Let me examine Lady Justice on the façade of the Judicial Court of Vila Nova de Famalicão (built in 2007) (Fig. 2).

This is a really thought-provoking image in my opinion, since justice is depicted holding the scales and the sword. Although she is not blindfolded, her dress shows the four phases of the moon. I wonder if the image points towards the existence of an unbalanced justice, one that is emotional, irrational and hard to understand ${ }^{11}$ ? Or, on the contrary, that, in addition to being logical and argumentative, justice needs to be sensible to the kind of matters at stake?

\footnotetext{
11 As in King Crimson's song Three of a Perfect Pair, we could perhaps say the artist was thinking the Law has his contradicting views, Justice has her cyclothymic moods and they both make a study in despair... See http:/www.lyricsfreak.com/k/king+crimson/three+of+a+perfect+pair_20078571.html [last accessed 02/09/2016].
} 
It also makes me wonder, if the artist wanted to point out exactly that justice, like a woman, is influenced by the phases of the moon, and consequently by the menstrual cycle! Here we need to consider that every aspect of the menstrual cycle, at one time or another, has been invoked to define women as incompetent (Scutt 1991). As Shklar (1990) recalls, women were treated as eccentrics who did not understand scientific reality or the rules established. We cannot forget that hysteria was the first mental disorder exclusively attributed to women; and even today, women keep on being called hysterical when they rebel against an order or when they contest the rules. From the 1950s onwards, the focus began to be on the menstrual cycle and associated theories relating to female deviant behaviour. Thus, as Scutt (1991) claims, premenstrual syndrome began to be used either as a defence or as a mitigation factor in a number of countries (such as in the UK and Australia). The argument generally runs that women are suffering from diminished responsibility during these times, and thus have no or little or lesser control over their actions. As Easteal (1991) argues, those who are concerned with gender equality are faced with a dilemma: although they do not want the small number of severe premenstrual syndrome sufferers to be dismissed as neurotic or charlatans, the primary concern is that people might generalize from the few and negatively stereotype all women or all those who experience premenstrual symptoms.

As Shaw (2010) has argued, women today are still expected to adopt a subordinate role, as much controversy still revolves around the differentiation of the public and private sphere: work, business, economics and politics versus domesticity, home and family. Such prejudice has served to generate a male sexual dominance over women, in every field of activity, embodied in a patriarchal culture that persists in many quotidian practices, including judicial proceedings. And in visual representations of justice.

\section{Enter Éowyn: On Swords, Masculinities and Women in the Legal Profession}

Now, one may ask: Why arm a woman? In the sixteenth century, it was extraordinary that a woman, even if she was an example of virtue, could wield a sword or adopt a warrior pose. Sword bearing was, in fact, a privilege of nobility and citizenship reserved to men. The sword of the warriors, tough bearded men, with all possible and imaginable traits of masculinity. According to McLaughlin (1990), in the later middle ages, chroniclers and other writers began to express astonishment at women's military activities. Yet, as the author argues, a surprising number of female warriors can be found in medieval sources (consider Jeanne D'Arc or Queen Elizabeth I, for example); still, female fighters of medieval Europe have largely been overlooked or dismissed. This disinterest reflects changing attitudes towards women who undertook masculine roles, for a variety of sanctions were directed at women who participated in warfare, ranging from restrictive legislation to ridicule, and charges of sexual misconduct or even witchcraft. Hence, we notice the impact of two structural developments in medieval society: the growing rigidity of role definition and the gradual divergence of the public and the 
domestic spheres (McLaughlin 1990). Thus, swords are linked to the concept of macho: macho means man, and particularly white man, and it implies both domination and protection of those under him, such as women (but also gay and black people). And by constructing people as non-macho one assigns them the function of being dominated (La Torre 2009). Which is quite ironic when it comes to Lady Justice holding the sword. Interestingly, though, as Warner (1985) also has perceived, warrior women could stand for virtue because, with carapaced bodies, they no longer tempted men.

Looking at the image of the warrior-woman, Lady Justice, another image comes to mind, Éowyn, one of the characters created by Tolkien. ${ }^{12}$ In the Two Towers, ${ }^{13}$ published in 1954, Tolkien introduces Éowyn, the White Lady of Rohan, a female character who plays a substantial role in the narrative of the Lord of the Rings. Éowyn's first appearance places her firmly within gender conventions and expectations (Downs 2014), for her role is clear: as a woman, Éowyn's place is in the home, watching over the needs of her uncle, king Theoden. She is also a Shield maiden, a warrior, and she performs both of these roles faithfully, but much to the torment of her soul (Woodard 2010). As Marness (1995) rightly points out, in the story Éowyn is the only human female with her own subplot, embarking upon her own quest and eschewing the trappings of conventional femininity. Thus, I consider Éowyn a really interesting character to examine, not only because she clearly calls the gender expectations upon her into question, but also because she is a woman-warrior and thus her image juxtaposes with that of Justitia, hence answering Resnik's (2002) question: "Why do we look at a robed woman with scales and sword and think 'Justice' or 'Law' - and not (...) warrior princesses?". Éowyn, from my point of view, is that warrior princess.

"What do you fear, lady?" Aragorn asks. "A cage", Éowyn replies. "To stay behind bars, until use and old age accept them, and all chance of doing great deeds is gone beyond recall or desire", she continues. Although, as Marness (1995) argues, Tolkien has been criticized for his supposed gender stereotyping, this is an amazingly modern sentiment in a work by a male Catholic medievalist in his sixties, published just after the English translation (1953) of Simone de Beauvoir's The Second Sex, where the idea of the cage is strongly connected to that of the female body (Seigfried 2013). Continuing the dialogue between Éowyn and Aragorn, the latter tells her that she cannot come with him on to The Paths of the Dead because her people need her. He tries to dissuade her and basically tells her it is her duty to stay behind, something he would never say to the men around him, such as Éowyn's uncle or brother. And she calls him on it. She tells him: "All your words are but to say: you are a woman, and your part is in the house". Éowyn's despair to claim a place among her male relatives as a warrior and hero is clearly evident, and she demands equality with men now that her obligations as her uncle's nurse are fulfilled, thus rejecting the gender roles she had been assigned (Downs 2014).

\footnotetext{
12 In Peter Jackson's films The Lord of the Rings: The Two Towers (2002) and The Lord of the Rings: The Return of the King (2003), Éowyn is played by actress Miranda Otto.

13 The second volume of Tolkien's trilogy The Lord of the Rings, after The Fellowship of the Ring (1954).
} 
As we are aware, in most Western countries, only recently did women gain full legal capacity. Nonetheless, our visual traditions of justice have their political roots in hierarchical, non-democratic States that tolerate inequalities. Most times certain categories of persons (in this case, women) were excluded from the circle of rights and power. Which brings us to the restriction of access to academic and liberal professions ${ }^{14}$ related to the Law-and a first parallel can be drawn here with Éowyn's case. In Portugal, it was only in 1918 that women were allowed to be barristers: Regina Quintanilha was the first Portuguese woman attorney. It was only after the democratic revolution of 1974 that women could enter the judiciary; in 1975, the first woman public prosecutor - Cândida Almeida-was appointed, and the first female Portuguese judge-Ruth Garcêz-was appointed in 1977 (Duarte et al. 2016). The first time a woman got a PhD degree in Law was in the year 1954, however she had to wait more than a decade to be able to teach. In the twenty-first century, in Portugal there is an evident feminization of the judiciary: in 2015, from a total of 1990 judges in first instance courts, Appeal Courts and the Judicial Supreme Court and the Administrative Supreme Court, 1175 were women (59\%) (Duarte et al. 2016). While we witness a growing feminization of the judiciary, there continues to be limited access to academic and influential positions, although some small changes have taken place, as Justice in Portugal, as said, is now headed by women.

Just like Éowyn, the first women who entered the legal profession were encouraged to leave the lawyering to men, for, as it was argued, the court's work was a male thing, a gladiatorial arena little suited to the kindness of sex, and that women lacked a legal mind; or that the peculiar qualities of womanhood, its gentle graces, its purity, its delicacy and its emotional impulses were not qualifications for forensic strife (Tacchi 2009; Rhode 2001). In 1894, Anna Kuliscioff (2011), talking about the first female lawyers in Italy and Belgium, claimed that they were rejected with the mocking pretexts of pregnancy, lactation, of the beret hat that did not fit hair styling, the gown that was not suitable to the tournure. In 1878, Clara Foltz became the first woman to be admitted to practice in the state of California, but she attempted to disguise her refusal to be confined within female roles by explaining that "a knowledge of the law of our land will make women better mothers, better wives, and better citizens" (Heilbrun and Resnik 1997). Nowadays, nonetheless, denigration still includes expression by judges and fellow lawyers of traditional beliefs regarding the social role and nature of women; demeaning comments about women, statements about female counsels' dress or appearance that diminish stature as a professional in the eyes of litigants or witnesses (Kay and Gorman 2008). And, most importantly, female lawyers have to face indirect discrimination that materializes in salary discrepancies, unequal opportunities in career advancement, the low number of women in leadership roles, and the confinement of female lawyers/judges to certain areas of practice, often the least lucrative (Duarte et al. 2014).

\footnotetext{
14 And alongside the issue of access to the professions, there is also the question of unequal access to law and justice. Unequal between men and women. But also uneven among women as well.
} 
The work/family conflict is as well one of the greatest concerns of women legal professionals. Most female attorneys feel that they do not have sufficient time for themselves and their families, and report high levels of stress in juggling their responsibilities (Rhode 2001). Here we can make a parallel with Lady Justice's scales and give them a more modern symbology: on the one hand, one can claim the scales call for gender equality; on the other hand, they recalls us that women have to keep on balancing the values of having a family and pursuing a career, even more so when it comes to one that relates to justice. Moreover, the question of child-rearing is twofold: in some circumstances it serves to reinforce the good qualities of female judges as mothers, as reported by Roberts (2014) regarding the Australian context, which, of course, does not explain why motherhood, as distinct from fatherhood, qualifies someone as a good judge or lawyer; or, on the contrary, it serves to reinforce the stereotype that motherhood and having a family affects their professional performance, as argued by Duarte et al. (2014) for the Portuguese context. Thus, the statue of Lady Justice, by sculptor Graham Ibbeson, standing in front of the Middlesbrough Combined Court Centre, ${ }^{15}$ in the United Kingdom, is quite fitting here: Lady Justice as a female judge, wearing a robe; but we can also interpret it as the image of a mother of two pesky kids, trying to talk some sense into their heads (as a judge would normally do). And in this context, it can be read in accordance to the societal expectations that to be a good mother a woman lawyer must be physically present and that her career must be subservient to the needs of her children. And, at the same time, that her familial duties intersect with her judicial obligations. It is also interesting to see her bare feet on the ground, as a reminder that justice needs to be grounded to reality and leave emotions aside (a contrasting image to that of Famalicão, mentioned earlier), or that judges must be humble and impartial. But Justitia's naked feet here can serve as a different metaphor: they remind us of the particular challenges faced by women lawyers as a consequence of the gendered nature of legal practice, and that career choices are accompanied by the imposition of sacrifices. As Duarte et al. (2014) have shown, Portuguese female magistrates seem to be more willing to reject promotion in favour of the family, namely if the promotion requires moving to another city or district.

Let us go back to Éowyn, in The Return of the King ${ }^{16}(1955)$ : in a subversive act of defiance, or transgression, Éowyn disguised herself as a male soldier, and travelled with the Riders of Rohan to the Battle of the Pelennor Fields outside the White City of Minas Tirith in Gondor. The first female lawyers were transgressors too, for they defied conventions and social expectations and entered the battlefield of the Courts. During the battle in Pelennor, Éowyn fought the Lord of the Nazgul after Theoden had been hurt by him. He then threatened that "no living man may hinder me", to which Éowyn, after taking off the helmet concealing her woman figure and identity, replied: "But no living man am I! You look upon a woman. Éowyn I am (...)". Her action is especially significant, as Downs (2014) states,

\footnotetext{
15 For a picture of the statue go to: http://www.geograph.org.uk/photo/4031236 [last accessed 06/09/ 2016].

16 This is the third and final volume of Tolkien's The Lord of the Rings.
} 
because she accomplished her action not in spite of her gender, but because of it. ${ }^{17}$ Another parallel is evident here: in order to gain access to the profession, whether as attorneys or judges, women had to adopt behaviours and attributes considered masculine. Wearing a gown, robe or wig (as Éowyn wore the helmet) does more than neutralizing and, thus, professionalize the individual. According to Watt (2012), the suit is the lawyer's uniform, and in wearing it, lawyers send out the message that conformity is their creed. A conformity that is also a masculinisation of the female form, voice, and action. As argued by Thornton (1998), women in law are primarily constituted in 'corporeal terms', producing and reproducing dominant notions of masculinity and femininity, revealing how this binary is invoked in an endeavour to retain the masculinity character of legal practice. Even when it comes to popular television series or movies, women lawyers attempt to play the men's game, and the woman is rarely completely successful both as professional and as woman (Corcos 2003).

Éowyn's transgressive behaviour, and her resemblance to Lady Justice as a female warrior, also raises another question. As Lochak argues (2011), from the moment the law grants individuals a sexual identity, male or female, it does nothing more than consecrate an undisputed biological attribute. But isn't the law itself establishing as 'natural' what would be a social construct? We could well explain law's resistance to absorb situations that fall outside the gender duality scheme such as transgender persons, which calls into question the allocation of a gender identity based on the dichotomous distinction of male and female (Lochak 2011). Despite significant advances in contraception, and also on the acceptance of homosexuality and transsexuality, the sexualisation of the subject by the law remains an unequal act masked by the natural character of the allocation of gender, connected to gender expectations (Borrillo 2011), which has also sustained the reading of lesbian women as masculine. Therefore, Ilic's picture ${ }^{18}$ (2004) of the quite feminine Ladies Liberty and Justice as a same-sex couple is really remarkable. In Portugal, same-sex marriage was legally consecrated in 2010, through Law no. 9/2010. However, same-sex couples were not allowed to adopt until very recently (Law no. 2/2016), which, again, brings back the question of family roles, motherhood and gender stereotypes. In the practice context, as Rhode (2001) reminds us, race, class, ethnicity, disability, age, and sexual orientation can be as important as gender in defining professional opportunities and concerns. So, I guess we can then say that the king of the Nazgul isn't quite dead yet....

Women's admission to law was but the initial challenge to male exclusivity in the legal profession. The next significant hurdle confronting women was the search for employment. Women who secured legal work were often offered opportunities in low-status specialties deemed suitable for women, such as probate and family law (Kay and Gorman 2008), and recent research has also shown that in the legal profession feminization is generally followed by a re-segregation of some sectors (e.g. family law) (Duarte et al. 2014). And here comes my last parallel with Éowyn:

\footnotetext{
17 Here a parallel with another character is needed, that of Portia, from the Merchant of Venice, by Shakespeare, in which she disguises herself as a man and then assumes the role of a lawyer's apprentice.

18 See http://www.mirkoilic.com/stock/index.php?album=collection\&image=MI010475H.jpg [last accessed 07/09/2016].
} 
recovering from her wounds in Gondor, she meets Faramir. It seems as if she is tamed by him. However, with the downfall of Sauron and the end of the war, Éowyn's heart changes. She has come of age and can now embrace her femininity. But she doesn't simply submit to her culturally designated role as a wife - she embraces an active career as a healer (Woodard 2010). If, initially, family law was a market niche left open by male colleagues and seen as more suitable for female law practitioners, in a second moment (from the 1970s onwards) family law offered the possibility of working from within a legal field where it was necessary to change rules and mentalities affecting the condition and situation of women (Tacchi 2009).

\section{Now Enters Niobe: On Race, Women and the Legal}

At this stage I would like to introduce Niobe, ${ }^{19}$ a character created by The Wachowskis $^{20}$ (played by actress Jada Pinkett Smith) for The Matrix franchise, and who serves as a supporting character in the two sequels of the original film, The Matrix Reloaded and The Matrix Revolutions, both released in $2003 .{ }^{21}$ Niobe is a human from Zion, being one of the rebels participating in the war against the Machines and the Matrix. She is the captain and pilot of the hovercraft Logos, the smallest ship in the human fleet. She is also one of Zion's most gifted martial artists; and the most skilled pilot among the rebel forces. In The Matrix Revolutions, Niobe manoeuvred the massive hovercraft Hammer through the narrow passage of a mechanical line (while under attack and pursuit by Sentinels), a feature no other pilot had successfully performed, and most importantly, one believed to be impossible by all of her male teammates (Kord and Krimmer 2011). In fact, we hear one of the captains say: 'Damn woman, you can drive!". As Lipp (2004) asserts, the Zion women in the trilogy serve as a challenge to the stereotype that women are not as competent with technology as men are: they are shown as professional in the use of all kinds of technical equipment, including computers, spaceships, motorbikes, helicopters, cars or weapons.

Niobe, in my opinion, can be seen as playing a double role: on the one hand, as a black Justitia fighting for the accomplishment of (social) justice in the real world of Zion; and, on the other hand, as a criminal in the virtual world of the Matrix, embodied by Agent Smith.

As claimed by Capers (2006), Justitia has an attribute that is rarely commented on, her whiteness. Actually, her whiteness is seen as something of a given, something assumed. Thus, the image of a black Lady Justice as the logo of the Brazilian Centro de Assessoria Popular Mariana Criola ${ }^{22}$ deserves our attention, as

\footnotetext{
${ }^{19}$ See http://www.imdb.com/character/ch0000743/ [last accessed 07/09/2016].

20 Theirs is also a really interesting story, intersecting with gender, for both are openly transgender women: Lana Wachowski (formerly Laurence "Larry" Wachowski) and Lilly Wachowski (formerly Andrew Paul "Andy" Wachowski).

${ }^{21}$ It is interesting to notice that both Éowyn and Niobe are secondary characters that appear in the sequels of both trilogies, but end up playing important roles for the success of the stories.

${ }^{22}$ The image can be accessed here: https://www.facebook.com/assessoriapopularmarianacriola/photos/a. 287616131404776.1073741825.287607564738966/287616138071442/?type=1\&theater [last accessed 07/09/2016].
} 
it transgresses Justitia's classical whiteness-as does Niobe when embodying the resistance to the dominant structure of power relations conveyed by the Matrix and Agent Smith. Mariana Criola as Justitia also frees herself from that dominant system conveyed by whiteness, as the broken slave chain indicates-Niobe also freed herself from the rules of the Matrix, thus defining her identity and privileging her agency. However, both images also call our attention to the fact that it is only a few non-white women that pursue a carrier as attorneys or in the judiciary (and when they wear the wig, women are not only cross-dressing as males, but non-white women are, in addition, cross-dressing themselves of another race). And if we consider the other spectre of the mirror, statistics also show that race matters when it comes to perceptions of crime and imprisoned population.

I chose Niobe particularly for those reasons, but also because her sunglasses remind me of Justitia's blindfold, and her guns are a modern device substituting the sword. In addition, as Gillis (2005) argues, Niobe not only offers an assertive counter to Trinity (portrayed by actress Carrie-Anne Moss), she is also a black woman who is able to step outside the confines of the (white) femme fatale, she proves to possess the competency and the ability usually associated with men, and she is someone who challenges all male authority (Jeffrey 2014).

Associating the sword of Justitia and Niobe's armament skills with the issues of masculinity/femininity also allows me to consider how criminal women are still regarded. Through time, crimes committed by women were generally perceived as less threatening than those committed by men, since men were expected to be violent and aggressive. Consequently, male deviation was seen as more intimidating, whereas women would be considered as inherently good or morally superior, until the day they became victims of physiological, psychological or adverse environmental influences (Burgess-Proctor 2006; Chesney-Lind and Pasko 2013; Keitner 2002). In addition, women are always seen as victims. Victimization corresponds to a certain essence of femininity and subordination. But don't we keep on assuming gender stereotypes here as well? Are women always the victims of injustice? Or are they too perpetrators of that injustice? Just think of the wrongs committed by white women to black women, and to black men too; think of female officials in fascist regimes, as in Germany and in Portugal. When roles are reversed, the deviation (deviation from the "normal deviation", which is male performed crime) is accentuated. Therefore, the criminal woman is not only seen as having an anti-legal behaviour, but also as going against gender expectations and roles. By being seen as a rebel in the Matrix, as a criminal, Niobe also embodies the reality we observe: the Matrix as a body of rules and a political system governed by white men-as played by Agent Smith—and a large percentage of arrested women coming from non-white segments of the population.

Thus, women in the legal profession also face a longstanding double standard. They risk criticism for being too soft or too strident, too aggressive or not aggressive enough since what appears assertive in a man often appears abrasive in a woman (Rhode 2001). Female attorneys often do not receive the same presumption of competence or commitment as their male colleagues. And the problem is even worse for black women (not to mention lesbians and disabled women). In the film, while Niobe is a heroic woman doing important work (it is Niobe who gives her ship 
to Neo), in the real world the kind of work done by black women is fairly low down on the chain of labour force (Gillis 2005).

\section{Some Conclusions}

As we know, new political, economic and social rights impacted familial, parental and marital relationships (not only in terms of gender roles, but also concerning the reconfiguration of the concept of gender and gender relations), but working conditions and salaries too, thus fragmenting the boundaries between the private and public spheres. This panoply of rights implied the reconfiguration of power and equality relations. However, the traditional image of Justitia remained. Shall we perhaps argue that the allegory of Lady Justice may not be adequate to represent a diverse population of rights' holders?

If we look closer, it appears that even when Justitia seems to leave her femininity aside she still imposes a role model on women. We thus face the question of gender roles and expectations linked to the lady-like stereotypes of Virtue, the asexual and respectable woman, and motherhood. On the other side of the spectre, we are confronted with the masculinisation of behaviours: on the one hand, the need to adopt a professional behaviour or way of acting and thinking as a man, in order to be accepted as a competent agent, be it as lawyers or, on the other side of the line, as offenders; on the other hand, this masculinisation of women's behaviours is criticized because it is seen as going against socially constructed gender expectations.

The virtuous Lady Justice compels women to be delicate, and hence opposite to a legal or criminal mind. In addition, women are confronted, as well, with the question of exceptionality: women have suffered from the failure of the legal system to take them seriously, to grant to them the same allowance that is extended to men-that of characters with full mental powers, with full human status, with the right to be regarded as human beings operating in this world (Scutt 1991). Thus, for women to be respected they have to endure societal adversities and behave as exceptional. Just like Lady Justice does! Nonetheless, race, class, ethnicity, disability, age, and sexual orientation have also to be connected with gender, and gender violence.

My intent is not that we should discard Justitia. And even less so to replace it by Éowyn or Niobe. My aim was to present a different reading of the image, more in tune with contemporary times, and relate the image with other characters that are part of our popular culture and call into question shared values regarding class, race, femininity/masculinity and the role of women in their connection to the law. As a result, the reinforcement of sexist attitudes through judicial institutions-and the courts' representation, as we know, still revolves around Justitia-exacerbate their hold on the popular mind (Keitner 2002). The symbols we use to embody certain values are a mirror of each society and its culture. And thus we may ask: how do we want to represent Justice in the twenty-first century? Is Justitia still enough? Or is the use of this symbol, still in the present day, a way to turn invisible not only the reality encountered by so many different women, but also the alternative symbols 
that may better represent a multicultural Justice? Actually, not much has been written about subversive representations of justice which serve to question or undermine dominant ideologies (Mulcahy 2013).

Perhaps, in the end, if we were to seat Lady Justice at the bench and to interrogate her, we would come to the conclusion that she is no more than a social and cultural device, which needs to be questioned and reflected upon in order to change social attitudes towards a more egalitarian model of society. Probably, she would merely reply: "I'm just a soul whose intentions are good, please, don't let me be misunderstood". ${ }^{23}$

Acknowledgements I would like to thank the suggestions made by Richard Mohr, Sabine N. Meyer, Morag J. Grant and Maria José Carvalho to an earlier version of this paper. I would also like to thank the valuable comments made by the two anonymous reviewers.

\section{References}

Borrillo, Daniel. 2011. Le sexe et le droit de la logique binaire des genres et la matrice hétérosexuelle de la loi. Jurisprudence. Révue Critique. Université de Savoie: Lextenso Éditions.

Branco, Patrícia. 2016. Courthouses as spaces of recognition, functionality and access to Law and Justice: A Portuguese reflection. Oñati Socio Legal Series 6 (3): 426-441.

Burgess-Proctor, Amanda. 2006. Intersections of race, class, gender, and crime: future directions for feminist criminology. Feminist Criminology 1: 27-47.

Capers, Bennett. 2006. On justitia, race, gender, and blindness. Michigan Journal of Race and Law 12: $1-31$.

Capers, Bennett. 2012. Blind justice. Yale Journal of Law and the Humanities 24 (1): 179-189.

Chesney-Lind, Meda, and Lisa Pasko (eds.). 2013. Girls, women, and crime. London: Sage Publications.

Corcos, Christine. 2003. "We Don't WANT Advantages": The woman lawyer and her quest for power in popular culture. Syracuse Law Review 53: 1225-1271.

de Ville, Jacques. 2011. Mythology and the images of justice. Law and Literature 23 (3): 324-364.

Dowd, Nancy E. 2013. Asking the man question: Masculinities analysis and feminist theory. In Exploring masculinities. Feminist legal theory reflections, ed. Martha Albertson Fineman, and Michael Thomson, 9-16. Farnham: Ashgate.

Downs, Jack M. 2014. Radiant and terrible: Tolkien's Heroic women as correctives to the romance and epic traditions. In A quest of her own: Essays on the female hero in modern fantasy, ed. Lori M. Campbell, 55-75. Jefferson: McFarland \& Company.

Duarte, Madalena, Ana Oliveira, and Paula Fernando. 2016. Gender and judging in Portugal: Opinions and perceptions. Oñati Socio-Legal Series 6 (3): 454-476.

Duarte, M., P. Fernando, C. Gomes, and A. Oliveira. 2014. The feminization of the judiciary in Portugal: dilemmas and paradoxes. Utrecht Law Review 10 (1): 29-43.

Easteal, Patricia. 1991. Women and crime: Premenstrual issues. Trends and issues in crime and criminal justice 31. http://aic.gov.au/media_library/publications/tandi_pdf/tandi031.pdf. Accessed 08 September 2016.

Gillis, Stacy. 2005. The matrix trilogy. London: Wallflower Press.

Goodrich, Peter. 2014. Legal emblems and the art of law. Obiter Depicta as the vision of Governance. New York: Cambridge University Press.

Goodrich, Peter. 1995. Oedipus lex. Psychoanalysis history law. Berkeley: University of California Press.

Heilbrun, Carolyn, and Judith Resnik. 1997. Convergences: Law, literature and feminism. In Beyond Portia: Women, law, and literature in the United States, ed. Joan St. Jacqueline, and Annette Bennington McElhiney, 11-52. Boston: Northeastern University Press.

23 "Don't Let Me Be Misunderstood" is a song written by Bennie Benjamin, Gloria Caldwell and Sol Marcus for the Jazz singer and pianist Nina Simone, who first recorded it in 1964. Cf. https://en. wikipedia.org/wiki/Don\%27t_Let_Me_Be_Misunderstood [last accessed 08/09/2016]. 
Jeffrey, Karima K. 2014. Mother of a new world? Stereotypical representations of black women in three postapocalyptic films. Journal of Feminist Scholarship 6: 1-12. http://www.jfsonline.org/issue6/ pdfs/JFS_Issue6.pdf. Accessed 08 September 2016.

Kay, Fiona, and Elizabeth Gorman. 2008. Women in the legal profession. Annual Review of Law and Social Science 4: 299-332.

Keitner, Chimène I. 2002. Victim or vamp? Images of violent women in the criminal justice system. Columbia Journal of Gender and Law 11 (1): 38-87.

Kord, Susanne, and Elisabeth Krimmer. 2011. Contemporary hollywood masculinities. Gender, genre, and politics. New York: Palgrave Macmillan.

Kuliscioff, Anna. 2011. Il Monopolio dell'Uomo. Aprilia: Ortica Editrice.

La Torre, Miguel. 2009. Beyond machismo: A Cuban case story. In Men and masculinities in christianity and judaism: A critical reader, ed. Björn Krondorfer, 444-459. London: SCM Press.

Lee, Rebecca K. 2012. Justice for all? Vanderbilt Law Review En Banc 65: 217-229.

Levit, Nancy, and Robert R. Verchick. 2006. Marriage and family. In Feminist legal theory. A primer, ed. Nancy Levit, and Robert R. Verchick, 163-173. New York: New York University Press.

Lipp, Martina. 2004. Welcome to the sexual spectacle: The female heroes of the Franchise. In Jacking into the matrix franchise. Cultural reception and interpretation, ed. Mathew Kapell, and William G. Doty, 14-31. New York: Continuum.

Lochak, Danièle. 2011. Dualité de sexe et dualité de genre dans les normes juridiques. Jurisprudence. Révue Critique. Université de Savoie: Lextenso Éditions.

Machado, Helena. 2007. Moralizar para identificar. Cenários da investigação judicial de paternidade. Afrontamento: Porto.

Marness, Kevin. 1995. Taming the Wild Shieldmaiden: A Feminist Analysis of Tolkien's "Heroinism" in The Lord of the Rings. http://www.academia.edu/363083/Taming_the_Wild_Shieldmaiden_A_ Feminist_Analysis_of_Tolkiens_Heroinism_in_The_Lord_of_the_Rings. Accessed 08 September 2016.

McLaughlin, Megan. 1990. The woman warrior: Gender, warfare and society in medieval Europe. Women's Studies 17: 193-209.

Mulcahy, Linda. 2013. Imagining alternative visions of Justice: An exploration of the controversy surrounding Stirling Lee's depictions of Justitia in nineteenth-century Liverpool. Law, Culture and the Humanities 9 (2): 311-329.

Nettel, Ana Laura. 2005. The power of image and the image of power: The case of Law. Word and Image 21 (2): 136-149.

Pedroso, João, Paula Casaleiro, and Patrícia Branco. 2014. A (des)igualdade de género nos tribunais de família e menores: um estudo de sentenças de regulação das responsabilidade parentais em Portugal. Estudos de Sociologia 19 (36): 81-100.

Resnik, Judith, and Dennis Curtis. 2011. Representing Justice: Invention, Controversy, and rights in citystates and democratic courtrooms. Yale: Yale University Press.

Resnik, Judith. 2002. Reconstructing equality: Of Justice, Justitia, and the gender of jurisdiction. Yale Journal of Law and Feminism 14 (2): 393-418.

Rhode, Deborah L. 2001. The unfinished agenda. Women and the legal profession. Chicago: American Bar Association.

Robert, Christian-Nils. 1993. La Justice. Vertu, Courtisane et Bourreau. Geneva: Georg Editeur SA.

Roberts, Heather. 2014. Telling a history of Australian women judges through courts' ceremonial archives. Australian Feminist Law Journal 40 (1): 147-162.

Scutt, Jocelynne. 1991. The incredible woman: A recurring character in criminal law. Women's Studies International Forum 15 (4): 441-460.

Seigfried, Karl E. 2013. Tolkien's heathen feminist. http://www.norsemyth.org/2013/02/tolkiens-heathenfeminist-part-one.html. Accessed 08 September 2016.

Shaw, Julia J.A. 2010. Against Myths and traditions that emasculatewomen: Language, literature, law and female empowerment. Liverpool Law Review 31: 29-49.

Shklar, Judith. 1990. The faces of injustice. New Haven and London: Yale University Press.

Sprague, Aileen. 2011. Women and the law: the symbolism and the reality. Roger Williams University Law Review 16 (2): 260-277.

Tacchi, Francesca. 2009. Eva Togata. Donne e professioni giuridiche in Italia dall'Unità a oggi. UTET Libreria: Turin.

Thornton, Margaret. 1998. Authority and corporeality: the conundrum for women in law. Feminist Legal Studies 6 (2): 147-170. 
União de Mulheres Alternativa e Resposta [UMAR]. 2015. Observatório de Mulheres Assassinadas da UMAR. Dados 2014. http://www.umarfeminismos.org/images/stories/oma/2014/OMA_2014_ Relat\%C3\%B3rio_Anual.pdf. Accessed 05 September 2016.

Warner, Marina. 1985. Monuments and maidens: The allegory of the female form. Berkeley: University of California Press.

Watt, Gary. 2012. Law suits: Clothing as the image of Law. In Visualizing law and authority: Essays on legal aesthetics, ed. Leif Dahlberg, 23-50. Berlin: Walter de Gruyter.

Woodard, Hannah. 2010. The Shieldmaiden of Rohan. Inklings Forever 7. https://library.taylor.edu/ dotAsset/0eba8a01-2afc-44c8-ae9b-ecac8045a282.pdf. Accessed 08 September 2016. 